\title{
実大コンクリート充填鋼管の繰返し局部座屈破断に関する実験的研究
}

\section{AN EXPERIMENTAL STUDY ON THE CYCLIC LOCAL BUCKLING FRACTURE OF FULL-SCALE CONCRETE-FILLED TUBES}

\author{
河 野昭彦*，松井千秋**，木村俊之***，田中幸仁*** \\ Akihiko KAWANO, Chiaki MATSUI, Toshiyuki KIMURA \\ and Yukihito TANAKA
}

\begin{abstract}
The low cycle fattgue following cyclic local buckling is one of the important fracture modes of concrete-filled tubular members (CFT members). The authors have already proposed a formula to estımate the loading cycles up to the fracture 'The formula has been empirically derived from the expenimental database of the small-sçale specimens such as the outside diameters are less than or equal to $101.6 \mathrm{~mm}$.' Therefore, the research need was remained for the scale effect in the fracture mode. From this point of view, the paper conducted the full-scale experiment in which the specimens have the outside diameters of $355.6 \mathrm{~mm}$ or $216.3 \mathrm{~mm}$ The experiment showed that (1) the scale effect might be negligible in the range of specimens, and (2) the estimation formula, to which a slight arrangement was done to enlarge the parameter range of diameter-to-thickness ratios, was applicable to the full-scale specimens too
\end{abstract}

Keywords: $\quad$ concrete filled tube, local buckling, fracture, earthquake resistant capactty, scale effect コンクリート充填銅管，局部座屈，破断，耐震性能，寸法効果

1. 序

コンクシート充填鋼管 (CFT) 部材が繰返し荷重を受ける場合の破 壊形式の一うは, 局部座屈部分が破断するという形式である.この場 合の局部座屈はいわゆる象足形座屈で, 局部座屈発生から破断に室る まで多くの加力サイクルを必要とする大変安定した形式である1). そ こでその領域の変形あるいはエネルギー吸収を積極的に利用するた め, 著者はこの破壊形式の破断サイクルの予測式を提案したが2), 3), この予測式は外径 $101.6 \mathrm{~mm}$ 以下の小口径 CFT 試験体による実験式で あった.しかし，破断現象は寸法の影響を受けると考えられるので， 実際によく使用される範囲で，しかも脆性破壊はしない程度の寸法を． 目標として, 外径 $355.6 \mathrm{~mm}$ と $216.3 \mathrm{~mm}$ の CFT 試験体の実験を計画し た、いずれはこの破断現象も理論的に解明されるべきであるが，まず は実験データの蓄積が必要であると考えた. 実験は, これらのCFT試 験体に繰返し曲げを作用させて，局部座屈破断させるものである.

CFT 部材の局部座屈破断は, 既往の繰返し軸力を作用する実験か ら, 曲げ座屈に対する座屈長さには無関係で, 危険断面近傍の最外縁 の変位振幅に強く関係することが分かっている.これによれば, 荷重 が軸力であるか曲げであるかなど, 荷重の種類にもほとんど関係しな いはずである. 本研究はこの点にも考察を加えている.ただし，破断 を決定する最外縁の変位振幅は, 部材の寸法や荷重条件から骨組解析
などによって求めることになる。さら゙に，銅管の径厚比もこれまでの 50 を越える60の試験体が含められており，これまでの破断予測式に 対して, 径厚比の適用範囲を拡大すると同時に径厚比を連続量として 取り扱えるよう修正を加えた。

\section{2. 実験概要}

\section{1 実験変数}

実験变数は, 鋼管の断面寸法を 2 種類（外径 $D=355.6 \mathrm{~mm}$, $216.3 \mathrm{~mm})$ ，それぞれの断面寸法で鋼管の径厚比を 3 種類, および荷 重条件の 3 種類である. 荷重条件の1.番目は, 図1(a)に示すように試

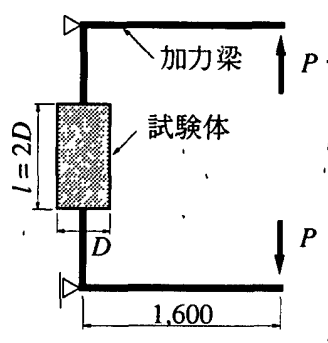

(a) 等曲げ

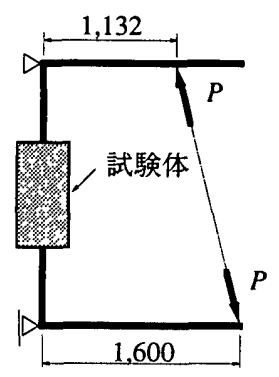

(b) 曲げせん断
図1荷重条件

\footnotetext{
* 九州大学人間環境学研究科 助教授. 工博

** 九州大学人間環境学研究科 教授. 工博

*** 九州大学人間環境学研究科 大学院生

Assoc Prof, Graduate School of Human Environment Studies, Kyushu University, Dr Eng

Prof, Graduate School of Human Environment Studies, Kyushu University, Dr Eng

Graduate Student, Graduate School of Human Environment Studies, Kyushu University
} 


\section{表1 実験変数}

\begin{tabular}{|c|c|c|c|}
\hline 試験体 & $D(\mathrm{~mm})$ & $D / T$ & 荷重条件 \\
\hline C312-1 & 355.6 & 294 & 等曲け，両振り \\
\hline C $312-2$ & " & 294 & 等曲げ，片振り \\
\hline C $312-3$ & " & 29.4 & 曲げ剪断, 両振り \\
\hline C $309-1$ & " & 394 & 等曲げ，両振り \\
\hline C 309-2 & " & 39.4 & 等曲げ，片振り \\
\hline C $309-3$ & $"$ & 39.4 & 曲げ剪断，両振り \\
\hline C 306-1 & $"$ & 593 & 等曲げ，両振り \\
\hline C $306-2$ & " & 59.3 & 等曲げ，片振り \\
\hline C $306-3$ & " & 593 & 曲げ剪断，両振り \\
\hline C209-1 & 216.3 & 276 & 等曲け，両振り \\
\hline C 209-2 & " & 27.6 & 等曲げ，片振り \\
\hline C 206-1 & $"$ & 39.6 & 等曲げ，両振り \\
\hline C 206-2 & " & 396 & 等曲げ，片振り \\
\hline C 204-1 & $"$ & 47.9 & 等曲げ，両振り \\
\hline C 204-2 & $"$ & 47.9 & 等曲げ，片振り \\
\hline
\end{tabular}

験体に繰返し等曲げを両振りで作用するもの，2番目は，やはり図 1 (a)に示す絽返し等曲げであるが，これを片振りで作用するもの， 3 番目は, 両振り載荷であるが, 図1(b) に示すように両端で偏心量をや や変化させ,曲げと共に僅かなせん断も作用するものである. 荷重の 制御は，図1(a)に示すように，試験体の材長 $2 D$ の相対たわみ角振幅 で行い，いずれも振幅を一定として，試験体が破断するまで載荷す る.また, 図 1(a),(b)の荷重条件では, 試験体の軸力が変動すること になるが，偏心量が大きいために変動量は断面の圧縮酎力の高々 $6 \%$ である.これらの実験変数をまとめて表 1 に示す.

\section{2 試験体および加力装置}

試験体は図 2(a), (b)に示すように $D=355.6 \mathrm{~mm}, 216.3 \mathrm{~mm}$ の円形鎆 管にベースプレートを取り付けてコンクリートを充填したものであ る. 試験体の材長はいずれも $1,200 \mathrm{~mm}$ であるが，塑性化させる部分 は材中央の鎆管外径Dの 2 倍長の部分であり，それ以外の部分は同種 の銅管を縦に 2 分割したものをカバープレートとして溶接して補強し ている. 充填コンクリートは絴打ちとし, ベースプレート中央の打設 用孔から充填した.ベースプレートには空気抜き用の小孔がありこ の孔から空気が逃げたことを確認した上で打設を終了した。

使用した材料は，銅管はSTK400の冷間成形電綘鋼管であり，充填 コンクリートはポルトランドセメントと最大精径 $20 \mathrm{~mm}$ の粗骨材を使 用し，設計強度30MPaを目標に調合した普通コンクリートである。鋼
表2 鋼管の寸法と材料特性

\begin{tabular}{|c|c|c|c|c|c|c|c|c|}
\hline $\begin{array}{c}\text { 鋼管 } \\
(\mathrm{mm})\end{array}$ & $\begin{array}{c}D \\
(\mathrm{~mm})\end{array}$ & $\begin{array}{c}T \\
(\mathrm{~mm})\end{array}$ & $\begin{array}{c}A \\
\left(\mathrm{~mm}^{2}\right)\end{array}$ & $\begin{array}{c}\sigma_{y} \\
(\mathrm{MPa})\end{array}$ & $\begin{array}{c}\sigma_{u} \\
(\mathrm{MPa})\end{array}$ & $\begin{array}{c}\varepsilon_{u} \\
(\%)\end{array}$ & $\begin{array}{c}\text { 伸び } \\
(\%)\end{array}$ & $\begin{array}{c}\mathrm{YR} \\
(\%)\end{array}$ \\
\hline $355.6 \phi \times 12$ & 3556 & 1209 & 1305 & 360 & 431 & 13.1 & 20.6 & 83.6 \\
$355.6 \phi \times 9$ & 355.6 & 904 & 98.4 & 349 & 432 & 11.2 & 19.1 & 808 \\
$355.6 \phi \times 6$ & 355.6 & 599 & 65.8 & 394 & 465 & 11.6 & 18.0 & 84.6 \\
$216.3 \phi \times 9$ & 216.3 & 7.85 & 514 & 399 & 473 & 11.1 & 16.3 & 84.4 \\
$2163 \phi \times 6$ & 216.3 & 5.46 & 362 & 422 & 494 & 11.5 & 16.5 & 855 \\
$216.3 \phi \times 4$ & 216.3 & 4.52 & 30.1 & 404 & 483 & 11.3 & 14.0 & 83.6 \\
\hline
\end{tabular}

$D$ : 外径, $T$ : 管厚, $A$ : 断面積, $\sigma_{y}$ : 降伏応力度, $\sigma_{u}$ : 最大応力度, $\varepsilon_{u}:$ 最大応力度時のひずみ, YR: 降伏比

表3 充填コンクリートの調合

\begin{tabular}{|c|c|c|c|c|c|c|c|}
\hline $\begin{array}{l}\text { セメント } \\
\left(\mathrm{kg} / \mathrm{m}^{3}\right)\end{array}$ & $\begin{array}{c}\text { 水 } \\
\left(\mathrm{kg} / \mathrm{m}^{3}\right)\end{array}$ & $\begin{array}{l}\text { 細骨材 } \\
\left(\mathrm{kg} / \mathrm{m}^{3}\right)\end{array}$ & $\begin{array}{l}\text { 粗骨材 } \\
\left(\mathrm{kg} / \mathrm{m}^{3}\right)\end{array}$ & $\begin{array}{l}\text { 高性能 } \\
\text { 減水材 } \\
\left(\mathrm{kg} / \mathrm{m}^{3}\right)\end{array}$ & $\begin{array}{c}\text { 水セメ } \\
\text { ント比 } \\
(\%)\end{array}$ & $\begin{array}{r}\text { スランク } \\
(\mathrm{cm})\end{array}$ & $\begin{array}{l}\text { 空気 } \\
\text { (\%) }\end{array}$ \\
\hline 333 & 163 & 755 & 1087 & 0832 & 49 & 12 & 50 \\
\hline
\end{tabular}

表4 充填コンクリートの材料特性

\begin{tabular}{|c|c|c|c|c|c|}
\hline 試験体 & $\begin{array}{c}c^{\sigma_{B}} \\
(\mathrm{MPa})\end{array}$ & $\begin{array}{c}\varepsilon_{u} \\
(\%)\end{array}$ & 打設日 & 試験日 & $\begin{array}{c}\text { 材齢 } \\
(\mathrm{B})\end{array}$ \\
\hline C306-1,C309-1 & 33.7 & 0.19 & 1998.10 .2 & 1998.11 .12 & 41 \\
C312-1,C209-1 & 36.0 & 0.15 & 1998.10 .2 & 199811.20 & 49 \\
C204-1,C206-1 & 350 & - & 1998.10 .2 & 1998.12 .04 & 63 \\
C306-2, C309-2, C312-2 & 37.7 & 0.18 & 1998.10 .2 & 1999.6 .18 & 259 \\
C204-2, C206-2, C209-2 & 42.3 & 0.18 & 1998.10 .2 & 1999.6 .4 & 245 \\
C306-3,C309-3,C312-3 & 410 & 0.17 & 1998.10 .2 & 1999.6 .25 & 266 \\
\hline
\end{tabular}

${ }_{c} \sigma_{B}: 100 \phi$ のシリダー圧縮強度, $\varepsilon_{\mu}$ : 圧縮強度時のひずみ

管の寸法と材料特性を表 2 にコンクリートの調合と材料特性をそれ ぞれ表 3 および表 4 に示す.

図3は加力装置である.試験体の両端のベースプレートは加力梁に 高力ボルトで接合される. 加力梁の他端は押 · 引 $1000 \mathrm{kN}$ 能力の油圧 ジャッキがロードセルを介してピンで接続されている．加力梁は $\mathrm{H}$ $588 \times 300 \times 12 \times 20$ のロールH形鋼をカバープレートで補強したものであ る. 油圧ジャッキが押しの場合は, 試験体には引張軸力と曲げモーメ ントが作用する.このときを正側加力とする. 既述のとおり軸力変動 は相対的に小さい. 図3は等曲げの場合を示しているが，曲げせん断 を作用する場合は, 図1(b)のように油圧ジャッキの片側のピンの位置 を $500 \mathrm{~mm}$ ほど内側へずらす，実験は加力装置を水平に配置して，理 研機器 (株) 製の自動加力装置で油圧ジャッキを駆動して遂行した。

変位は図4(a)に示すようにC F T 試験体の材中央の検長 $2 D$ 間の最 外縁変位を変位計 2 台で測定した. 検長の変位は測定治具のスライド 量として現れ,これを変位計で測定する. 測定治具のスライドはリこ

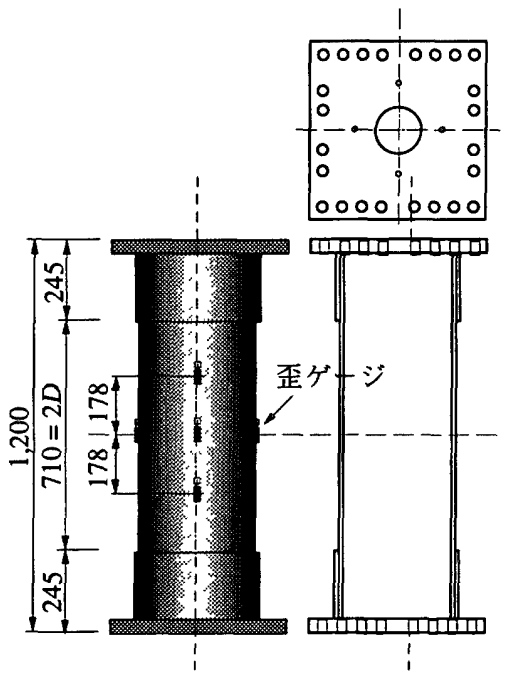

(a) 外径 $355.6 \mathrm{~mm}$ 試験体

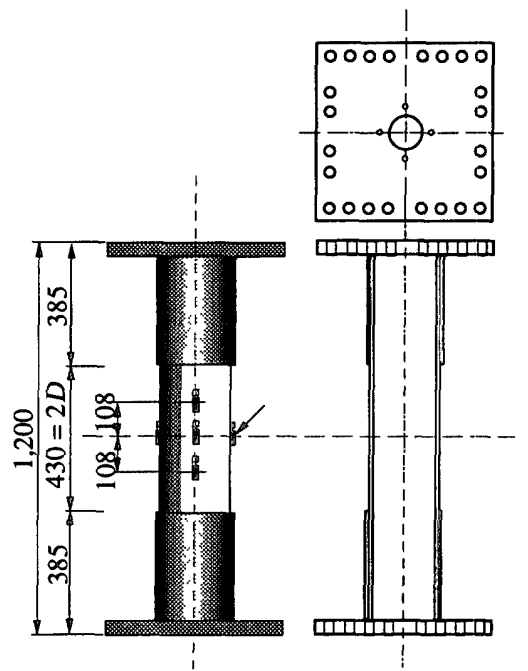

(b) 外径 $216.3 \mathrm{~mm}$ 試験体

図2 CFT試験休

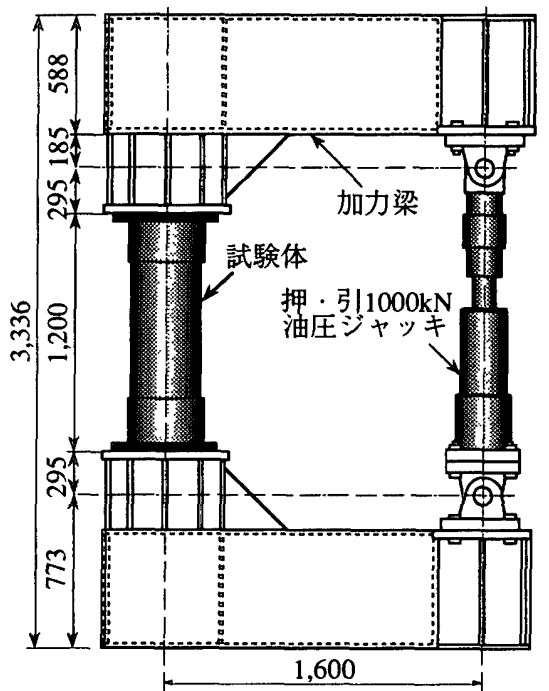

図3 加力装置 


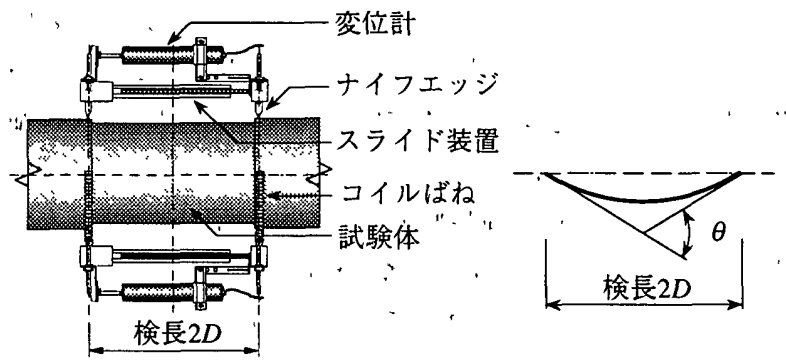

(a) 変位計と測定治具 図4 变位の測定

アモーションベアリングを用いたスライド装置でがたうきなく行われ る.試験体にはバネを使ってナイフェッジで試験体を挟むように取り 付けられている. 二つの変位計の值の差をDで除したものは検長 $2 D$ 間の相対たわみ角 $\theta$ に相当する. 加力制御はこの $\theta$ で行った.. 歪は図 2(a)および(b)に示す位置に貼付した歪ゲージによって測定した。

\section{3 実験結果}

\subsection{1 実験耐力と破壊モード}

.表 5 に最大荷重 $P_{\text {max }}$, 局部座屈発生時の, 加力, サクル数 $n_{l b}$, 破断時 の加力サイクル数 $n_{c}$ ，および破断位置を示す. 表 5 の $P_{\max }$ ，計算值は, 表 2 の $\sigma_{y}$ と表 4 の ${ }_{c} \sigma_{B}$.を用いた SRC 規準の一般化累加式4）による終 局強度であり，比率は実験値を計算值で除したものである．ただし， 充填コンクリートの圧縮強度の低減率 $\check{r}_{U}$ は1.0としした。 また, 試験体 の軸力変動も考虑しているが, 曲げ耐力に及ほす影響は小さい. 表か
表'5 実験結果による耐力と破断

\begin{tabular}{|c|c|c|c|c|c|c|c|c|c|c|c|}
\hline \multirow[b]{2}{*}{ 試験体 } & \multicolumn{6}{|c|}{$P_{\max }$} & \multirow[b]{2}{*}{$n_{\text {bb }}$} & \multirow[b]{2}{*}{$n_{c}$} & \multirow{2}{*}{$\begin{array}{l}\text { 破断 } \\
\text { 位置 }\end{array}$} & \multirow{2}{*}{$\begin{array}{r}A_{2 D} \\
(\%)\end{array}$} & \multirow[b]{2}{*}{ L B } \\
\hline & \multicolumn{3}{|c|}{ 正側加力 } & \multicolumn{3}{|c|}{ 負側加力 } & & & & & \\
\hline C312-1 & 416 & 351 & 119 & -427 & -374 & 114 & 1 & 39 & 端部 & $\frac{10}{4.40}$ & $2>1$ \\
\hline C $312-2$ & 434 & 350 & 1.24 & -356 & -376 & 095 & 1 & 38 & 端部 & 3.96 & $2>1$ \\
\hline С $312-3$ & 503 & 391 & 1.29 & $-518^{\circ}$ & -434 & 119 & $1^{\prime}$ & -15 & 端部 & 4.56 & 1 \\
\hline С 309-1 & 307 & 262 & 1.17 & -323 & -285 & 113 & 1 & 22 & 端部 & 4.42 & $2>1$ \\
\hline C 309-2 & 341 & 264 & 1.29 & -262 & -288 & 091 & 1 & 14 & 中央 & 4.42 & $\therefore 1$ \\
\hline C $309-3$ & 397 & 295 & 1.35 & -411 & -333 & 1.23 & 1 & 8 & 端部 & 5.37 & 1 \\
\hline C $306-1$ & 226 & 204 & 1.11 & -235 & -225 & 1.05 & 1 & 9 & 中央 & 472 & 1 \\
\hline C $306-2$ & 249 & 208 & 120 & -174 & -229 & 076 & 1. &.-9 & 端部 & 4.76 & $2>1$ \\
\hline C $306-3$ & 291 & 229 & 1.27 & -310 & -264 & 117 & 1 & 5 & 端部 & 5.66 & 1 \\
\hline C209-1 & 104 & 937 & $1.11^{\prime}$ & -111 & -97.6 & 113 & 1 & 51 & 端部 & 4.16 & $2>1$ \\
\hline C 209-2 & 115 & 937 & 122 & -91.1 & -983 & 093 & 1 & .45 & 端部 & 411 & $2>1$ \\
\hline C 206-1 & 835 & 721 & 1.16 & -89.2 & -75.7 & 118 & 1 & 25 & 端部 & 411 & $2>1$ \\
\hline C 206-2 & 711 & 73.3 & 097 & -73.5 & -769 & 0.96 & 1 & 18 & 端部 & 430 & $2>1$ \\
\hline C 204-1 & 65.2 & 582 & 112 & -75.0 & -617 & 1.21 & 1 & 15 & 端部 & 4.09 & $2>1$ \\
\hline C 204-2 & 735 & 595 & 1.24 & -53.9 & -624 & 086 & 1 & 11 & 端部 & 4.42 & $2>1$ \\
\hline
\end{tabular}

$P_{\text {max }}$ : 最大荷重, $n_{l b}:$ 局部座屈発生サイクル数, $n_{c}:$ 破断サイクル数

ら, 等曲げ・片振りの試験体の負側加力時の実験耐力は最大耐力を発 揮する変形に達していないので計算値との比率はやや低いが, それ以， 外は実験值が計算值によって安全側に評価されていると言える.

表の $A_{2 D}$ は, 危険断面の最外縁の $2 D$ 間変位振幅で, 図 4(a)の 2 台 の変位計のうち破断した側の変位計で測定された変位振幅を検長 $2 D$ で除した值であり,後述の荷重変形関係がほほ定常状態になった時点 での振幅を読み取ったものである.

すべての CFT 試験体は，鋼管の破断で崩壊した。まず，第 1 サイ クルで局部座屈が鋼管全長にわたって数波生じ, その後, 2 波あるい

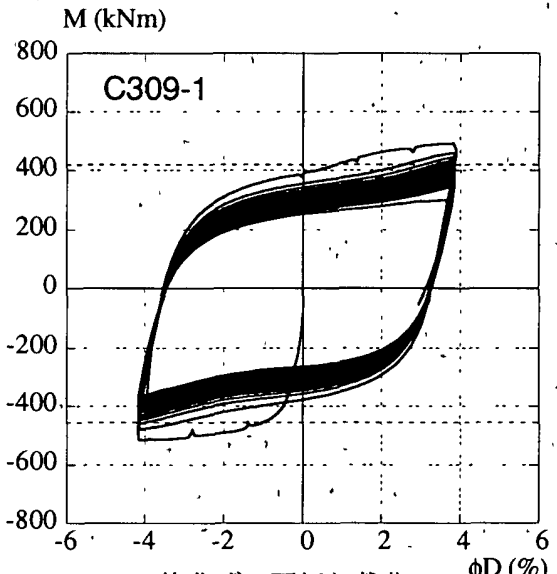

(a) 等曲げ, 両振り載荷

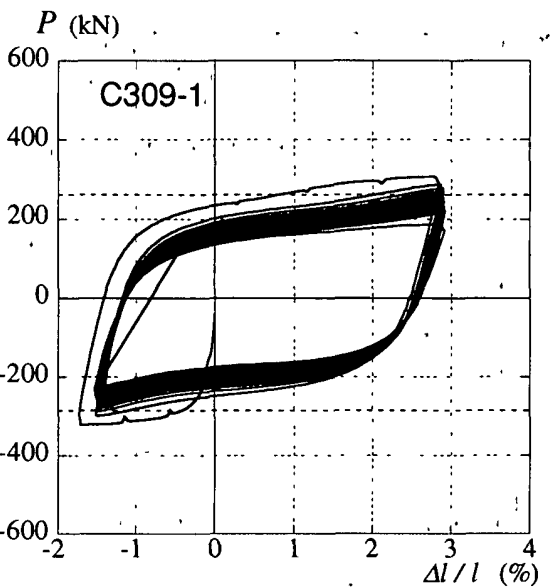

(a) 等曲げ, 両振り載荷

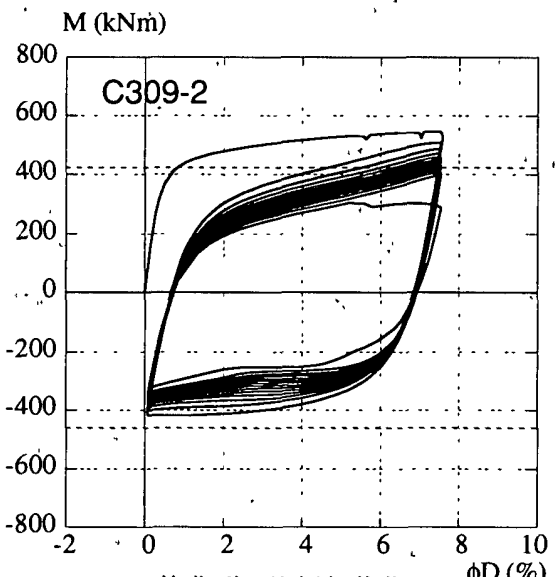

(b) 等曲げ,、片振り載荷

図5 $M$ - $\phi$ 関係 $(D=355.6 \mathrm{~mm}, D / T=39.4)$ $P(\mathrm{kN})$

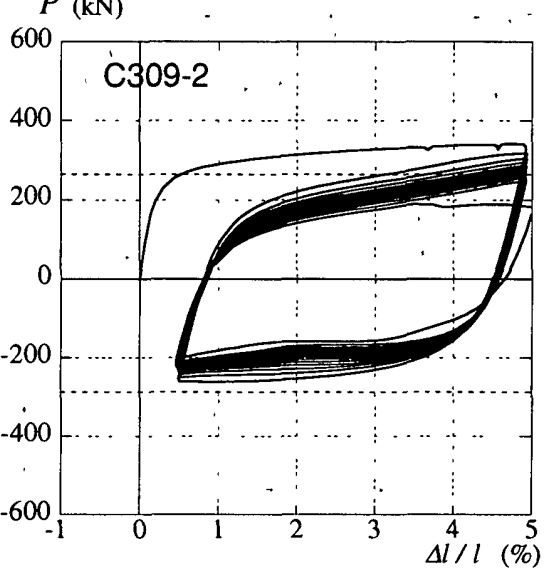

(b) 等曲げ, 片振り載荷

$\Delta l / l(\%)$

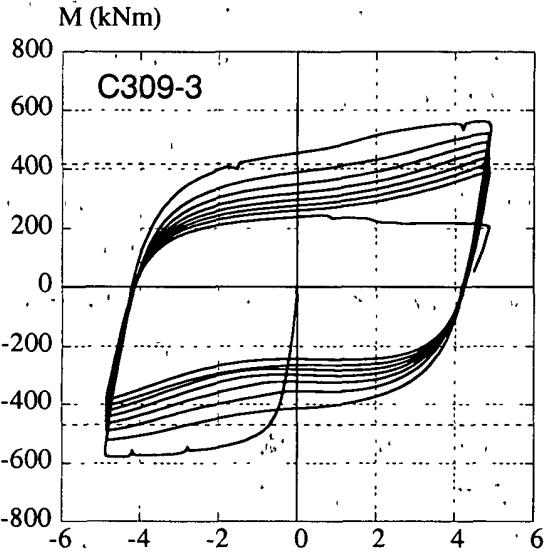

(c) 曲げせん断, 両振り载荷 $\phi \mathrm{D}(\%)$

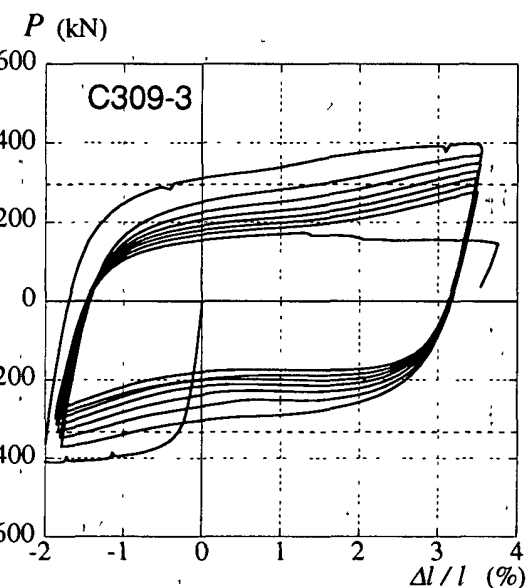

(c) 曲げせん断，両振り載荷

図6 " $P \cdot A_{2 D}$ 関係 $(D=355.6 \mathrm{~mm}, D / T=39.4)$ 
は 1 波が成長し, 残りは目立たなくなった。破断は成長した局部座屈 の山で生じた．Dが216.3mmの試験体およびDが $355.6 \mathrm{~mm}$ の試験体 のうちC312-1, C312-2, C309-1, C306-2は, 最終段階まで局部座屈が両 端に 2 波成長してどちらで破断しても不思議ではない状態であった. 表 5のL.B. 闌に示す”2>1”のマークがその挙動を表す. 試験体 C3092 とC306-1 は材中央の1波だけが成長して破断した（"1").曲げ剪断 を受けるC312-3，C309-3，およびC306-3ではモーメントが大きな方 の端部に 1 波だけが成長した. 破断サイクル数 $n_{c}$ は 2 波が同時に成長 する場合と初期から 1 波だけが成長する場合では大きく異なってい る.つまり，2 波同時の場合は一つの局部座屈部分の膨らみは小さ く, $n_{c}$ は多くなった.

\subsection{2 荷重-変形関係}

図 5(a)〜(c)は，D=355.6mm，D/T=39.4の CFT 試験体の曲げモー メント $M$ と曲率 $\phi$ 関係を示している.ただし，曲げせん断を受ける 場合 [図 5(c)]の $M$ は大きな方の材端曲げモーメントを表す．他の試 験体についてもほほ同様な履歴曲線が得られている，図では，曲率 $\phi$ にDを乗じた無次元化曲率 $\phi D て ゙$ 表している．結局， $\phi D$ は相対たわ み角 $\theta$ の 2 分の 1 に対応する. 図5(a)は，等曲げが両振りで作用した 場合で，局部座屈が 2 波同時に成長し続けたものである．図5(b)は， 等曲げた片振りで作用した場合で, 局部座屈は材中央の 1 波だけが成 長した. そのため破断サイクル数 $n_{c}$ は両振りに比べて半減している. 図(c)は，曲げせん断が作用する場合で，モーメントが大きな方に局部 座屈が 1 波だけが成長した.この場合は曲率振幅も大きいためにさら に $n_{c}$ が減少している.図中の点線は一般化累加式による終局強度を表 しており，おおむね良好な一致が見られる．ただし，Mが負の時は圧 縮軸力が作用している。

図 6(a) (c) は, 図 5(a) ( (c) と同じ CFT 試験体の荷重 $P$ と検長 $2 D$ の

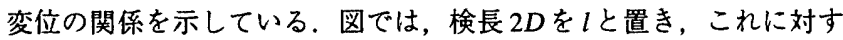
る変位を $\Delta l て ゙$ 表している。 $\Delta l$ は亀裂が先に生じた側の $2 D$ 間変位であ る.図から分かるとおり，第2サイクル以降は， 化せず，この值を読み取ったものが表 5 の $A_{2 D}$ である。

\section{3. 破断サイクル数と予測式}

\section{1 破断サイクル数 $n_{c}-A_{2 D}$ 関係}

図 7(a) ( (c) は，破断サイクル数 $n_{c}$ と $2 D$ 間変位振幅 $A_{2 D}$ の関係を表 す．図では，既往の実験結果2),3)は黒丸で，今回の実験結果は白丸ま
たは白三角で示している，ただし，今回の実験結果のうち，最終段階 まで局部座屈が 2 波同時に成長したものは，読み取った $\Delta / /$ 振幅の 塑性変形成分 (弾性変形の除いた成分) を 2 分の 1 に低減して評価し て $A_{2 D}$ に換算した. それは， $\Delta M の$ 塑性変形成分は主として局部座屈 部分によるものであり，局部座屈が 2 波同時に存在する場合はこの塑 性変形成分が両者に二分されると考えられるからである。

文献2)では次式で表される破断サイクル数 $n_{c}$ の予測式を提案した。

$$
\begin{array}{ll}
D / T=20 \cdot & n_{c}=180 \exp \left(-37 A_{2 D}\right) \\
D / T=30: & n_{c}=60 \exp \left(-29 A_{2 D}\right) \\
D / T=50 \cdot & n_{c}=20 \exp \left(-21 A_{2 D}\right)
\end{array}
$$

図7(a), (b), (c) のそれぞれに D/Tが20，30，50の場合の上式の值を実 線で示している. 図7(a) は黒丸で示される既往の小口径試験体 $(D \leqq$ $101.6 \mathrm{~mm})$ の実験結果だけであるが, 対応関係は良い. 図 7(b), (c)に は白丸あるいは白三角によって今回の大口径試験体（ $D=355.6 \mathrm{~mm}$, $216.3 \mathrm{~mm}$ ) の奏験結果も併せて示している. 図 7(b)の $D / T=30$ の場合 では, 既往の小口径試験体と今回の大口径試験体の破断サイクル数 $n_{c}$ は $A_{2 D}$ が同じであればほほ同じであり，予測式に対する対応関係もよ い. 図7(c) ではD/Tが50以外の 40 と60の奏験値も示しているが，D/ $T=40$ の実験值はおおむね予測式の上側に，60の実験值はおおむね 等しいか下側に位置していて対応関係は悪くない.

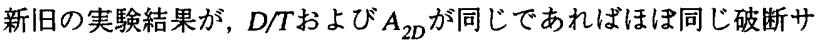
イクル数 $n_{c}$ を示したこと, さらに(1)式の破断予測式と良い対応を示 したことから，次の知見が得られる．第 1 は，破断サイクル数 $n_{c}$ は， 軸力, 等曲げ, あるいは曲げせん断, または, 両振り・片振りなどの 荷重条件には直接の関係はなく， $A_{2 D}$ のみに関係する. 第 2 は, 外径 が355.6mm 程度までは破断における寸法効果の影響を無視でき，予 測式は新旧の実験結果と良く対応している。ただし， $D / T か ゙ 40 と 60$ の場合を表現できないので，この点を次節で修正する。

\section{2 修正破断予測式}

(1)式の予測式に対して, 径厚比を連䄯変数として取り扱えるよう修 正を加える. (1)式は図 7(a)〜 (c)に示すように, $n_{c}$ の対数值が $A_{2 D}$ と線 形関係にあるとするものである.なお,ここには示していないが, 通 常の疲労曲線に準じて $n_{c}$ と $A_{2 D}$ の両対数を線形関係とすると, $A_{2 D}$ が 小さい領域と大きい領域で危険側誤差が大きくなることが分かってい る.(1)式は $A_{2 D}$ が 0.14 のときに破断サイクルが 1.0 になるような片対

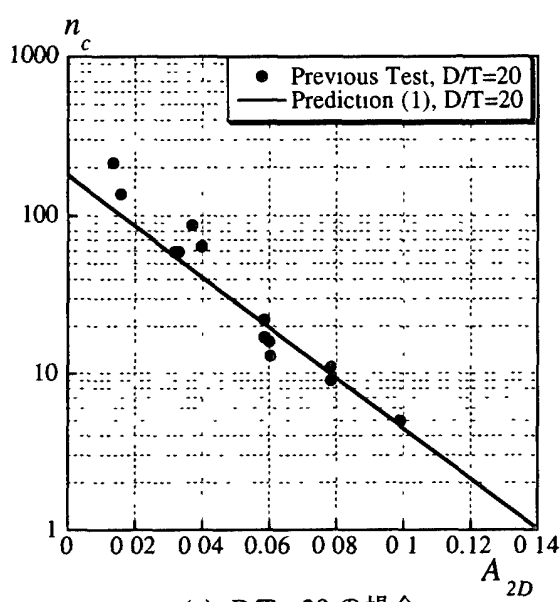

(a) $D / T=20$ の場合

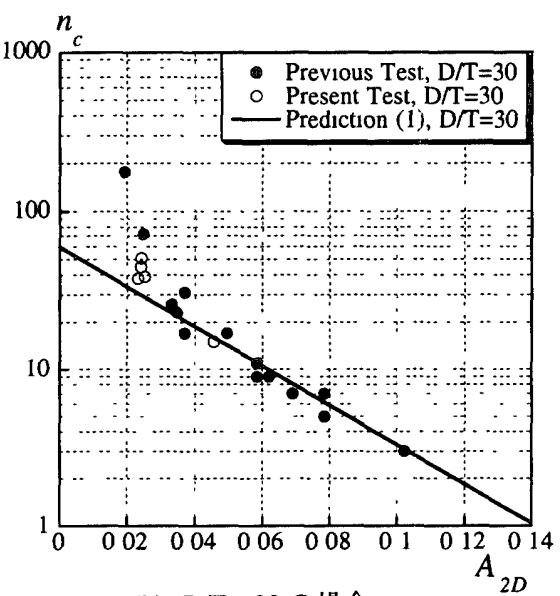

(b) $D / T=30$ の場合

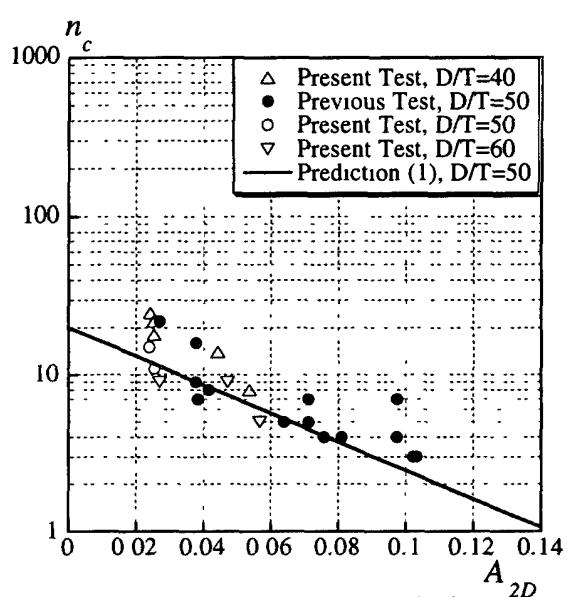

(c) $D / T=40,50,60$ の場合

図7 破断サイクル数 $n_{c}$-最外縁 $2 D$ 間変位振幅 $A_{2 D}$ 関係 


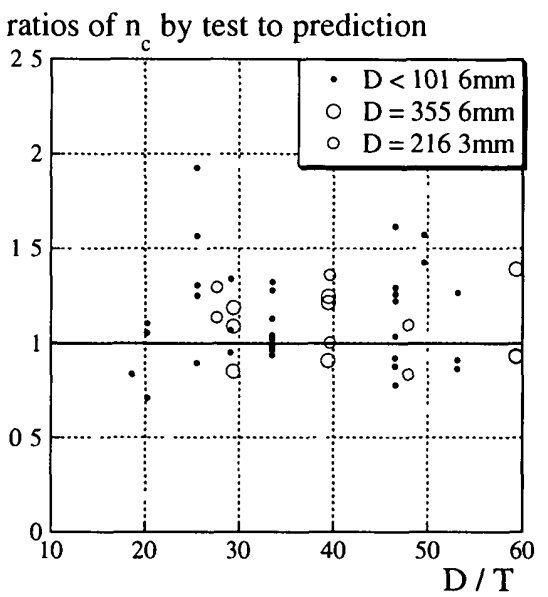

(a) $D / T$ の変化に対する予測精度 ratios of $\mathrm{n}_{\mathrm{c}}$ by test to prediction

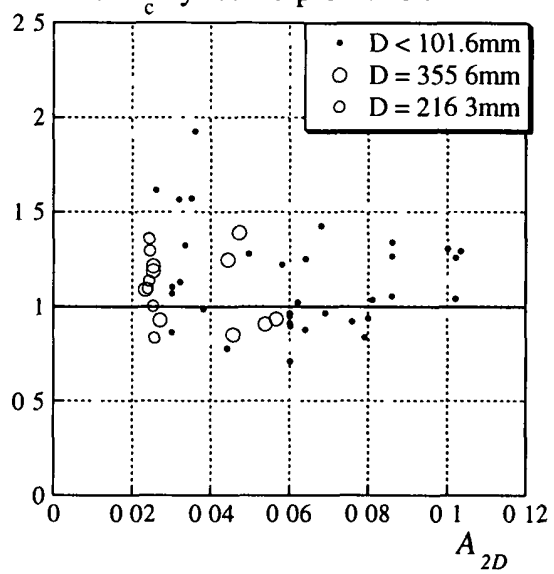

(b) $A_{2 D}$ の変化に対する予測精度

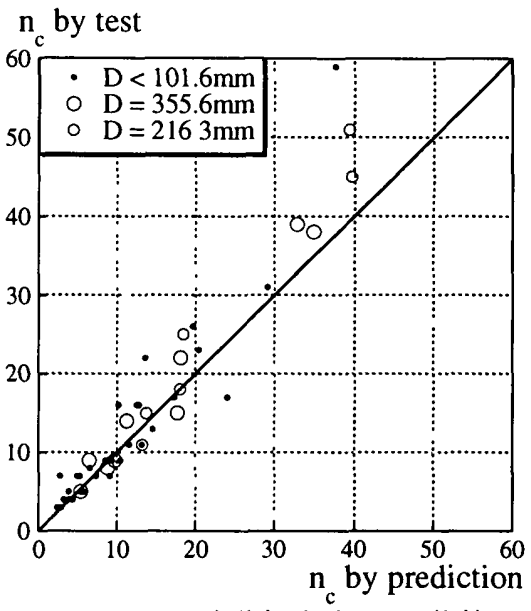

(c) 実験と予測の $n_{c}$ の比㜞

図8 破断サイクル数 $n_{c}$-最外縁 $2 D$ 間変位振幅 $A_{2 D}$ 関係

数の直線関係になっており，次のように表される.

$$
n_{c}=\exp \left\{a\left(0.14-A_{2 D}\right)\right\}
$$

上式の $a$ を径厚比 $D / T$ 関数と考えることにする.これまでの実験結 果に基づき,かつ,(1)式の予測式とほほ同程度の評価を与える簡単な 式として次式を導出した。

$$
n_{c}=\exp \left\{\left(10+\frac{600}{D / T}\right)\left(014-A_{2 D}\right)\right\}
$$

図 8(a)は，実験の破断サイクル数 $n_{c}$ と(3)式の新予測式による $n_{c}$ の 比率を $D / T$ に対して示したものである.これによって, 新予測式は, D/Tの変化に対してほぼ一様な比率で, 実験の下限值に近いところを おさえていることが分かる. 図8(b)は, 同じく実験值と予測值の比率 を $A_{2 D}$ に対して示したものである.この図より，新予測式は $A_{2 D}$ に対 してもほほ一様な比率で実験值を評価していると言える。

図 8(c)は, 実験の $n_{\mathrm{c}}$ と新予測式の $n_{c}$ の比較である. $A_{2 D}$ が $2 \%$ 未満 の場合は局部座屈がなかなか発生しない場合もある.そこでこれらを 除いた 51 体分で統計量を求めると, 実験值と予測値の比率は平均で 1.16, 変動係数は $27.7 \%$ であった. ばらつきはあまり小さくないが, 工学的使用に十分耐え得るものと考えられる.

\section{4. 結論}

実大と考えてよい程度の CFT 部材に対して繰返し曲げあるいは曲 げせん断を作用する実験を行い，以下のような知見を得た.

(1) 実験から得られた耐力は, SRC規準の一般化累加式による終局強 度とほほ良い一致を示した。

（2）破壊形式は，すべて鋼管部分の局部座屈後の破断であった，等曲 げを作用した試験体の局部座屈は両端部に 2 波が最終段階まで成長し 続ける場合と材中央に 1 波だけが成長する場合の 2 通りがあった. 両 者の破断サイクルはかなり異なっているが, 前者の2D間変位振幅 $A_{2 D}$ の塑性成分を 2 分の 1 に換算すれば妥当な結果になる。

(3) 径厚比 $D / T$ と $2 \mathrm{D}$ 間変位振幅 $A_{2 D}$ が同じならば, 今回の大口径（ $D$ $=355.6 \mathrm{~mm}, 216.3 \mathrm{~mm})$ のCFT試験体と既往の小口径 $(D \leqq 101.6 \mathrm{~mm})$ の CFT 試験体の破断サイクル数には有意な差は認められない。した がって，この程度の断面寸法では寸法効果の影響を無視できる。

(4) 既往の CFT試験体は軸力, 今回の CFT 試験体は等曲げあるいは曲
げせん断を作用したものである。これらの破断サイクル数は， $D / T$ と $A_{2 D}$ だけで決定され，そのとき荷重の種類は無関係であった．

(5) 径厚比を連続量として取り扱えるように修正を行った新予測式を 提案した. 新予湘式は $A_{2 D}$ が $2 \%$ 未満を除いた全 51 体分の実験結果を 平均值 1.16 , 変動係数 $27.7 \%$ で予測した。

\section{参考文献}

1) A. Kawano and C. Matsu1: An Experımental Study on Hysteretic Behavior of Concrete Filled Tubular Members under Repeated Axıal Loading, Proc. of Ninth World Conference on Earthquake Engineering, Tokyo-Kyoto, 1988.8, Vol. IV, IV-133-138.

2) 河野昭彦, 松井千秋, 中島隆裕, 高木潤一: 繰返し軸方向力を受 けるコンクリート充填銅管部材の座屈挙動とエネルギー吸収能力 に関する実験的研究，日本建築学会構造系論文報告集，第 482 号， 1996.4, 131-140.

3) A. Kawano and C. Matsu1 : Bucklıng Behavior and Aseısmic Property of Concrete-filled Tubular Members Under Cyclic Axıal Loadıng, Proceedings of an Engineering Foundation Conference on Composite Construction in Steel and Concrete III, ASCE, 1997.8, 602-615.

4）日本建築学会：鉄骨鉄筋コンクリート構造計算規集・1987.6.

5）木村俊之, 河野昭彦, 松井千秋, 田中幸仁: 実大コンクリート充 填龬管柱の局部座屈後破断則に関する研究, 日本建築学会九州支 部研究報告, 第 38 号 11 構造系, 1999.3, pp.577 580.

6) 木村俊之, 河野昭彦, 松井千秋, 田中幸仁: 実大コンクリート充 填鋼管柱の局部座屈後破断の実験研究, 日本建築学会大会学術講 演梗概集，構造 III， C-1，1999.9，pp.1267-1268.

註 本論文の一部は文献 5)，6)に発表済みである.

\section{謝辞}

本研究は文部省科学研究費基盤研究 (C) (2)「繰返し荷重下のコンク リート充填鎆管部材の局部座屈後破断則に関する研究」(代表：河野 昭彦）によった，九州大学文部技官の久島昭久氏と有働文久氏には, 加力装置・測定装置の製作と調整, 加力・測定機器の選定と調整に多 大なる協力を頂いた．また，試験体の製作は（株）徳田鉄工所にお願 いした。ここに記して深甚なる謝意を表します。

(2000年 1 月 7 日原稿受理, 2000 年 5 月 16 日採用决定 